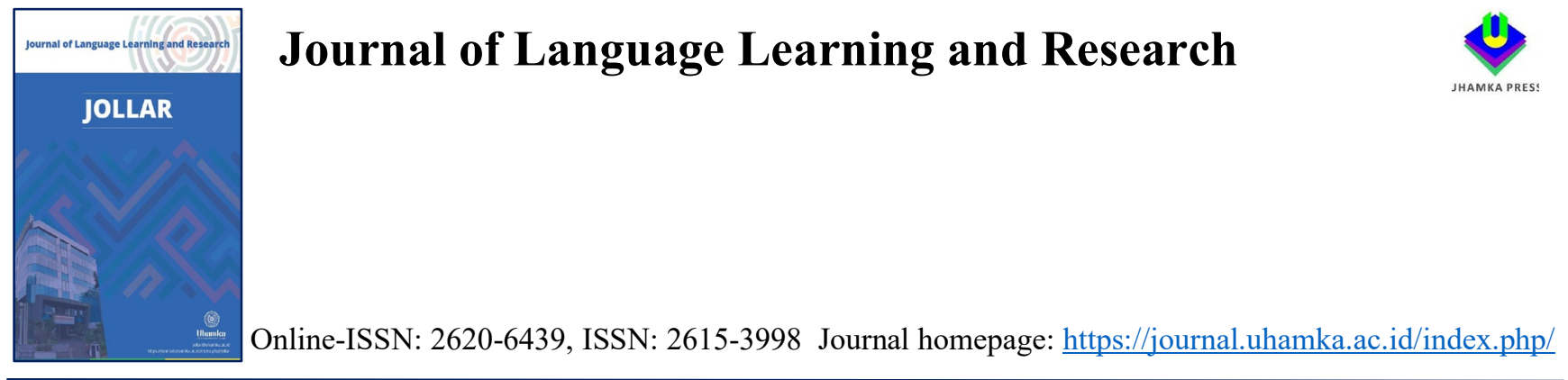

\title{
A Conversation Analysis of Adjacency Pairs in the Ellen DeGeneres's Talk Show with Malala Yousafzai
}

\section{Trihartina Tampubolon}

How to cite : Tamppubolon., T., 2019. Analisis Tindak Tutur (Speech Act) Pada Percakapan Antara Tetangga Dekat. Journal of Language Learning and Research. 2(1). 1-11. https://doi.org/10.22236/jollar.v2i1.3492

To link to this article: https://doi.org/10.22236/jollar.v2i1.3492

(C)2021. The Author(s). This open access article is distributed under a Creative Commons

Attribution (CC BY-SA) 4.0 license.

Published Online on 11 Maret 2020

A Submit your paper to this journal

View Crossmark data 5 


\title{
A Conversation Analysis of Adjacency Pairs in the Ellen DeGeneres's Talk Show with Malala Yousafzai
}

\section{Trihartina Tampubolon}

\begin{abstract}
This research aims to find out the application of the types of adjacency pairs in a conversation script "Malala Yousafzai" in talk show of Ellen DeGeneres. The writers used the conversation analysis approach to support research in analyzing data. Conversation analysis (CA) is the natural conversation that has participants two or more. Adjacency pairs is paired utterances by two different speakers. The method used is qualitative descriptive. The writer took the data from the "Malala Yousafzai" conversation script on Ellen DeGeneres's talk show. The data containing video and script, the duration is 8:09 minutes. This video is downloaded from http://www.eamus.it/videos/malala-at-ellens.htm. The writer analyzed the data by reading the script of the conversation and then classified the data according to the types of adjacency pairs. And then drawn conclusion. Adjacency pairs creates an obvious meaning in social interaction through conversation. Adjacency pairs has types and patterns. The pattern determines the meaning being delivered and minimize the misunderstanding between participants. And help people understand what people want to make particular language choices and what people mean. There are six types of the adjacency pairs found in "Malala Yousafzai" conversation script in Ellen DeGeneres's talk show.
\end{abstract}

Keywords : Adjacency pairs, Conversation analysis. 


\begin{abstract}
Abstrak
Penelitian ini bertujuan untuk mengetahui penerapan jenis jenis pasangan ajasensi dalam sebuah naskah percakapan 'Malala Yousafzai' di acara bincang-bincang Ellen DeGeneres. Penulis menggunakan pendekatan analisis percakapan untuk mendukung penelitian dalam penganalisaan data. Analisa percakapan merupakan sebuah metode untuk menyelidiki struktur dan proses interaksi sosial antara manusia. Salah satu cakupan analisa percakapan adalah pasangan ajasensi. Pasangan ajasensi adalah ungkapan berpasangan oleh dua orang pembicara yang berbeda. Metode yang digunakan dalam penelitian ini adalah kualitatif deskrptif. Penulis mengambil data dari naskah percakapan "Malala Yousafzai"di acara bincang- bincang Ellen DeGeneres. Data ini terdiri dari vidio dan naskah, dengan durasi 8:09 menit. Vidio ini diunduh dari http://www.eamus.it/videos/malala-atellens.htm. Penulis menganalisa data dengan membaca naskah percakapan dan mengelompokkan data menurut jenis jenis pasangan ajasensi yang digunakan. Dan kemudian menarik kesimpulan. Pasangan ajasensi membuat sebuah arti yang jelas dalam interaksi sosial melalui percakapan. Pasangan ajasensi memiliki jenis jenis dan pola. Pemahaman yang sebenarnya akan tersampaikan dan mengurangi ketidakpahaman antara peserta wawancara. Dan membantu orang-orang memahami pilihan bahasa yang digunakan dan maksudnya. Ada enam jenis the adjacency pairs yang ditemukan dalam naskah percakapan di acara bincangbincang Ellen DeGeneres's.
\end{abstract}

Corresponding author: trihartina97@gmail.com

2021. The Author(s). This open access article is distributed under a Creative Commons Attribution (CC BY-SA) 4.0 license. 


\section{INTRODUCTION}

The adjacency pairs is a part of conversation analysis. Conversations are the deal form of communication in some respects, since they allow people with different views on a topic to learn from each other. . Levinson (1983: 284) states that conversation is a familiar predominant talk in which all participants freely alternate in speaking. In addition Yule (1996: 71), creates an analogy for conversation. He says that conversation is like a dance with the conversational partners synchronizing their movements smoothly.

A successful conversation includes mutually interesting connections between the speakers or things that the speakers know. For this to happen, those engaging in conversation must find a topic on which they both can relate to in some sense. Those engaging in conversation naturally tend to relate the other speaker's statements to themselves. They may insert aspects of their lives into their replies, to relate to the other person's opinions or points of conversation.

Fairclough (2001:9) states "conversation is systematically structured, and that there is evidence of the orientation of participants to these structures in the way in which they design their own conversational turns and react to those of others." Conversation consists of two or more participants taking turns and only one participants speaking at any time.

In most conversations, the responses are a spontaneous reaction to what has previously been said. In entertainment talk shows, however, the topics of conversation are often pre-scripted. Meanwhile, "interacting with other people is not just a mechanic process of taking turns at producing sounds and words but is rather to a semantic activity or a process of making meanings." Eggin and Slade (1997:6).

To analyze conversation interaction between two people or more the appropriate theory was known as Conversation Analysis (CA). According to Schiffrin (1994: 232) "CA is like interactional sociolinguistics in its concern with the problem of social order, and how language both creates and is created by social context".

Conversation analysis (CA) research is assumed to be included in typically linguistic disciplines such as pragmatics, discourse analysis, or sociolinguistics. In fact, it started in American sociology by the lectures of Harvey Sacks and his coworkers - Gail Jefferson and Emanuel Schegloff in 1960s (Liddicoat, 2007: 4). Mazeland (2006: 153) states that the framework of Conversation analysis that used to focus on talk in conversations has gradually been extended to research of other types of talk such as medical and clinical interaction, lessons, or news interviews. For such reason, he concludes why the more general characterization talk in interaction nowadays is often preferred over conversation. 
The term "Conversation Analysis" is to represent any study of people talking together, "oral communication", or "language use". Paltridge (2000:83) says that conversation analysis, ordinary conversation is the most basic form of talk and the main way in which people come together, exchange information and maintain social relations.

There are five scope of Conversation Analysis, first is Adjacency pairs. Adjacency pair is characterized as paired utterances that are divided into a first pair part and a second pair part (Levinson 1983 : 303). Second, Turn Taking, is a situation when a speaker takes the chance to speak. Third, Preference Organization, is a possible answer uttered by second speaker as a response of the first speaker's utterance (Yule, 1996: 79). Fourth, Sequence Organization, is a stretch of utterances or turns as defined by Cutting (2002: 29). Fifth, Repair is a correction of what has been said by the speaker about the previous statement they said during the conversation.

In CA particular attention is given to everyday spoken interaction. As a student, the researcher also uses daily conversation interaction. Within this study, the researcher would like to help people understand what people want to make particular language choices and what people mean with some theory of discourse. This is what discourse is able to help people explain the relationship between what people say and what people mean. The discourse structure of conversation is generally less easy to predict than in many other genres. For example, conversations tend to be more openended and involved more shift in topic than is the case with some other genres.

In the process of communication, there will be automatic patterns which are produced by the speakers. The automatic patterns in the structure of conversation are called Adjacency pairs. The adjacency pair is the smallest unit of conversational exchange. Richards and Schmidt as cited in Patridge (2000, p. 87) explain that "Adjacency pairs are utterances produced by two successive speakers in such a way that the second second utterance is identified as related to the first one as an expected follow up". It is in line with Yule (1996) states that adjacency pairs contain two parts and are formed by two different speakers.

The concept of adjacency pairs consist of two parts of exchange in the conversation which second utterance is related and fuctionally dependent on the first utterance becomes a significant contribution of conversation analysis. They can be characterized as paired utterances that are divided in to a first pair part and a second pair part ( Levinson 1983 : 303).

From the definition of adjacency pair is paired utterances by two different speakers, the first speaker will stop talking and allows the second speaker. The response depends on the second speaker and naturally related to the first speaker. The nature of the firs utterance and the response enables the pairs to be classified into some types. 
There are some typical adjacency pairs proposed by some experts but the types maybe different from one expert to others. There is a compilation of adjacency pair types proposed by some experts : Paltridge (2000), Tylor and Tylor (1990), Levinson (1983), Coulthard (1985), and Schegloff (2006). The types of adjacency pairs that they propose are : announcement, apology, assertion, assessment, blame, command, complaint, compliment, greeting, invitation, leave taking, offer, question, requesting, suggestion, summon, threat, and warning.

Announcement is simply giving someone information. The second pair part of the announcement is acknowledgement. Apology normaly occurs after someone does something wrong states by Goddard (2011), and however he also adds that apology can also happens before someone making some imposition. Assertion means strongly believes that it is true about something. The response of an assertion is agreement or disagreement. Assessment can be formed into opinion seek or comment, which is asking another's opinion or agreement. Opinion seek is responded with opinion provide. Blame is utterances that express that someone is responsible about the mistake. Denial is statement to say that something is not true. The other response is admission.

Command is trigger a direct response. The response expected is usually semiautomatic and immediate. Command is similar to order where someone requires someone to do something immediately. Complaint is utterances which indicate feeling unsatisfied about something. However, apology is the way to response the complaint, which expresses regretfulness. Compliment is the way of praising another person about something he or she has. It is response with acceptance. Greeting is the way of saying hello and salutation. The response of greeting is greeting. Invitation is asks someone else to go to an event.

Leave taking, which is have purpose to end the conversation. Offer is utterances which giving something to someone, it may be in the form of goods or services. Acceptance is response indicates that the offer is accepted. Refusal is response indicates that the offer is refused. Question can be formed into information seek or clarification seek. It is about asking something to someone. It is responded with information provide or clarification provide which is referred as an answer. Request is asking someone else to do something. It can be responded with acceptance or refusal. 
Suggestion is gives some distance from idea that the speaker wants the addressee to do it. Summon is the order for someone to come to or be present at a specific place. It can also means when someone arranges a meeting of people. The response of it is answer. Threat is utterances that indicate the intension of harm. However, counter thret is utterances that express the defeat of someone's threat. Warning is utterances to warn someone about something. While acknowledgement is statements which show that the warning is already acceptable.

The writer thought that CA could be the appropriate tool to analyze the data and there are some aspects which cannot be explained by any theory. There are some overages in CA which can be performed to support the analysis. It can be said that conversation analysis is the common theory to analyze conversation in social media.

The analysis of conversation analysis phenomena has become a long standing interest in the recent decades. There are some previous researches which related to this research about conversation analysis. They seem to have various focuses of conversation analysis. For instance, the research might focus on the turn taking, overlaping, repair, grammar and interaction of conversation. The variation is not only in the focus but also on in the data.

The first research focus on repair of conversation analysis, the repair on Oprah Winfrey show by Nadya Sivanya Rheisa (2014) from Yogyakarta State University entitled "A Conversation Analysis of Repair in the Oprah Winfrey Show : A Special Episode with Michael Jackson".

The second research is focus on turn- taking of conversataion analysis. The entitled of research is "Conversation Analysis of Turn Taking Mechanism in Piers Morgan Tonight Talk Show by Nuryatul Ismaliyah (2015) from State Islamic University of Syarif Hidayatullah Jakarta.

The third research is focuses on 4 aspects of conversation those are adjacency pairs, topic management, preference organization and turn - taking. The entitled of research is "Conversation Analysis of the Interview between Oprah Winfrey and the Founder of Facebook Mark Zuckerberg by Putra Gigih Pamungkas (2012) from Dian Nuswantoro University Semarang. 
This research is based on the theory of conversation analysis and mostly based on the adjacency pairs exsisting in the conversations. This research discussed the problem of the research. The problem of the research is to find out the adjacency pairs included in the conversations between Ellen DeGeneres and Malala Yousafzai. To answer this problem of the research, the conception that adjacency pair consist of two parts of conversation which second utterance is related and dependent on the first utterance (Yule, 1996; Partridge, 2000,87; Levinson 1983,303). The research question requires the mentioning of the types of adjacency pairs. The types will be based on what have been proposed by Paltridge (2000), Tylor and Tylor (1990), Levinson (1983), Coulthard (1985), and Schegloff (2006). There are eighteen types of adjacency pair.

The writer analyzed the data based on experts above, to find out the types of adjacency pairs included in the conversation. The writer employed the conversation between Ellen DeGeneres and Malala Yousafzai as the data of the analysis because the writer thought that there are some interesting topics that contain in this data. Some of the reasons are that the topic becomes a trending topic in the world when Malala Yousafzai became the winner of Nobel Prize because she fight for education and as an inspiration for all women of any race, age, and religion. Besides that, Ellen DeGeneres show is a talk show that contains conversation interaction between the interviewer and the interviewee.

\section{METHODS}

This research used qualitative descriptive method as a research type. Descriptive research is used in the literal sense of describing situation or events (Isaac and Michael, 1987: 91). By using the qualitative descriptive method, this paper intended to find the adjacency pairs within the conversation between Ellen DeGeners and Malala Yousafzai.

The primary data of this paper were a video and script of the conversation between Ellen DeGeneres and Malala Yousafzai. The data containing video and script which take place in a studio on September 9, 2015 and the duration is 8:09 minute. This video is downloaded from http://www.eamus.it/videos/malala-atellens.htm.

There were some steps in collecting the data: The first, found the website for data on the internet. The writer searched on the internet from the website that provided the script of the interview. The second, downloaded the data conversation between Ellen DeGeners and Malala Yousafzai. The third, watched the video of the data. The writer took some time to watch the video of the conversation to matching each word the script of data and the video. 
After reading the script of the conversation, the writer analyzed the data. By reading the script of the conversation and then classified the data according to the types of adjacency pairs. And then drew conclusion.

\section{FINDINGS AND DISCUSSION}

This research is based on the theory of conversation analysis and mostly based on the adjacency pairs exsisting in the conversations. This research also discussed the problem of the research. The problem of the research is to find out the adjacency pairs included in the conversations between Ellen DeGeneres and Malala Yousafzai. To answer this problem of the research, the conception that adjacency pair consist of two parts of conversation which second utterance is related and dependent on the first utterance (Yule, 1996; Partridge, 2000,87; Levinson 1983,303).

The research question requires the mentioning of the types of adjacency pairs. The types will be based on what have been proposed by Paltridge (2000), Tylor and Tylor (1990), Levinson (1983), Coulthard (1985), and Schegloff (2006). The adjacency pairs pattern in the "Malala Yousafzai" conversation script in Ellen DeGeneres's talk show on September 9", 2015 entitled "The Incomparable Malala Yousafzai" are as follows :

\section{Assessment - Agreement}

This pair show that the first speaker express her feeling or opinion about the situation to the second speaker. And response to this pattern can be agreement or disagreement.

ELLEN

: "You really are so impressive and so inspirational, and I am so happy to have you here. I watched the documentary, I have read your book, and if you haven't, you must read this. It's quite a story. So you were shot in the face at 15 years old and you have no anger toward the man who shot you. How is that possible? MALALA : "I think they made a big mistake, because I was fighting for the right of education right from the beginning when the Taliban stopped girls from going to school. But I had this little bit of fear of that what would happen to me, how I would feel if someone attacks me, but after that incident when I was attacked, that fear just went away. And as I said in my speech at the United Nations, that my weakness, my fear, and my hopelessness died on that day. And I became stronger than before. And now I strongly believe that nothing can stop me in this mission and the campaign of education, to say that girls deserve the right to go to school and Iit's the love of people as well, that has encouraged me and helped me not to think about what I have been through in my life. When I see people praying for me, taking care of me, and sending cards and letters every day, it makes me stronger. 
It makes me stronger every day, and I feel that, whatever happened to me, I should now forget about it and continue my life with more courage and more work.

From the script above, it can be seen that Ellen expressed her feelings about Malala's courage to fight against the Taliban for girls' educational rights even though she has gotten a shot on her face. And response for the script that Malala agreed because she struggled for the right to education and became stronger than ever to continue her mission.

\section{Compliment - Acceptance}

This par show that the first speaker express her compliment of the situation, and response to this pattern can be acceptance or refusal.

ELLEN : "Well I am so glad that you came out of that experience as this person we are so lucky to have in the world, because you're making such a difference. You were in a coma for how long?"

MALALA : "At least a week."

ELLEN : "And then it took you a long time how to speak and walk and everything again..."

MALALA : "Yes. Then my parents came, and the doctors, they would bring the cards that I had received, and I just could not believe it. It was astonishing that - I'm going through this difficult situation but there's so much love out there, and it's helping me to forget about all the pain that I'm going through."

From the script above, it can be seen that Ellen expressed her compliment about Malala's recovery from coma. And Malala accepted the compliment by saying Yes. And she could through the difficult situation.

\section{Question - Answer}

The pattern of this pair show that the first speaker give question to the second speaker. Questions are used to seek information, clarification, confirmation, etc. And response to this pattern is answer the question.

ELLEN : "Yeah, there was a lot of love, a lot of people, and it really did raise awareness in a way that never had happened before. Your parents are in the audience right now, and I know that your dad empowered you tremendously. How did he do that?" 
MALALA : "Well, my father always says, 'Ask me not what I did, but ask me what I did not do,' and I did not clip her wings. So he has not clipped my wings, he has allowed me to fly as high as I can. This is how we want parents to be, to allow their children to fulfill their dreams, to achieve who they want to be. It's not that girls don't have the skill or don't have the talent to do something they want in their life, it's that they're stopped in society. So my father did not do that. He did not stop me; so I'm really thankful for him; also, to my mother for giving me the strength and the courage to move forward. A little bit to my brothers. A little bit." ELLEN : "A little bit."

From the script above, it can be seen that Ellen stated a question about how her dad empower her. And Malala answered the question by adding support comments.

\section{Question - Answer}

The first speaker give question to the second speaker. And the second speaker response to the first speaker.

ELLEN : "That is so well put, in every one of those things. I love your brothers, by the

way. It was good dancing with you. It was fun. So, you won the Nobel Peace Prize, and how did you find out you won?"

MALALA : "So, I was in my chemistry lesson in school, and -- just studying about atoms and those thing -- and suddenly my teacher came in, she surprised me and said, 'you have just won the Nobel Peace Prize." And I said, 'Okay.' And then I said, 'I want to finish my school, and-'cause I am standing up for education and I have been given this award because I am fighting for children's rights to go to school, so I deserve this right to study today in school, finish my school day, and then I'll go and have press interviews and stuff. So I finished that day."

ELLEN : "Right. Instead of talking to the press, you finished your school day. You just decided - well, and that's why you are who you are."

From the script above, it can be seen that Ellen stated a question about how could she know she won. And Malala answered the question by adding support comments.

\section{Opinion provide - Comment}

The pattern this pair show that the first speaker tells the second participant about certain events, state, or case. And response for this pair, the second participant makes a comment to that information.

ELLEN : "I think what's important here is that we take it for granted her, that girls go to school, and we are able to be educated, but I think that's really important for young girls here to understand that's not easy - women and children are not treated the same way in other countries." 
MALALA : "Well, I see children having this quality education, having all the facilities, classrooms, science labs, but unfortunately around this world, there are countries where children do not even have desks to sit, and they do not even have chairs. Some do not even have teachers in their school. Some do not even have schools at all. And I really think that education helps you to get an identity. It helps you to know about your basic human rights. It helps you to discover about yourself, about your talents, about your skills, and how you can help your community and your society. So, I did not want to be deprived of that, of that opportunity myself, and I want this for every child, that no child should be deprived of the basic human right of education."

From the script above, it can be seen that Ellen said her opinion that education is very important for women and children and not treated in the same way in other countries. And Malala agreed and responded with supported comments.

\section{Assertion - Agreement}

When the first speaker asserts something, it means he or she strongly believes that it is true. And the response to an assertion can be an agreement or disagreement.

ELLEN : "One thing I love about you. You're meeting all these world leaders, and you're not shy. You're meeting all these world leaders, and you say exactly what you think they should be doing. You met with President Obama and you told him he should stop flying drones. You just said that to him..."

MALALA : “... and the Congress members I met in my last trip in June, and it's very important that you deliver your message to the right people. And if you say--"

ELLEN : "Remember that, so y'all go to him next time, okay?

MALALA : "So if I like - if I feel shy, and if I think he would mind it, then these issues would never get highlighted. So it's telling the world, just reminding them of their duties. You're not asking to do something extra, but you're reminding them that these are their responsibility. They need to listen to their people's voices. We want them to take action. We want them to do something, and it's important that you highlight it to them."

ELLEN : "Yes, exactly. 18 years old, I was very similar to this."

From the script above, it can be seen that Ellen stated an assertion that Malala did not shy to meet with world leaders. And Malala made a response that she agreed and added with supportive comment, if she felt shy these issues would never be highlighted. 


\section{Suggestion - Acceptance}

The pattern of this pair show that the first speaker propose the suggestion to give the options, ideas, or something about the topic being discussed. And Acceptance can be the response when someone gives a suggestion.

ELLEN : "The problem that I see, because I've watched the documentary, and I've seen how many different places that you go to speak. Because you're 18 and you're shorter - you're not an adult-sized person yet."

ELLEN : "There's podiums that are too tall for you, so I got you something. So, it has a quote of mine, that says: 'Under every great woman is a tiny stepstool."

MALALA : "Thank you. Thank you."

ELLEN : "Also, I know for your $18^{\text {th }}$ birthday, there was something more important for you than gifts and you wanted to give money to a school that you started, right? Well, I would like to - this is an amazing thing. This is an iPad Air 2 and it has over 100,000 educational apps and tens of thousands of textbooks at your fingertips in here, and I want to make sure all of your students in Lebanon have the best possible headstart, so they're going to get this as well. They're going to give you 200 of these."

MALALA : "Oh, thank you. Thank you so much."

ELLEN

: "For more information on how you can donate to Malala Fund, you can go To malalafund.org. "He Named Me Malala" is in theaters October $2^{\text {nd }}$. We will be right back. Malala, everyone."'[cheers and applause, Malala stands on stepstool].

From the script above, it can be seen that Ellen suggested to give her stepstool to help her stand on the podium, and give her iPad Air 2 to help her students in Lebanon and advise everyone who wants to donate to the Malala mission. And Malala acceptsed her advice by saying thank you.

\section{CONCLUSIONS}

Conversation Analysis as an approach and an appropriate tool to analyze the data and there are some aspects which cannot be explained by any theory. Conversation analysis can help people understand what people want to make particular language choices and what people mean with some theory of discourse.

The adjacency pairs is a part of conversation analysis. The adjacency pairs creates an obvious meaning in social interaction through conversation. The pattern determines the meaning being delivered and minimize the misunderstanding between participants. There are six types of the adjacency pairs found in "Malala Yousafzai" conversation script in Ellen DeGeneres's talk show on September 9th 2015 entitled "The Incomparable Malala Yousafzai". They are : 1 Assessment - Agreement, 1 Compliment - Acceptance, 2 Question - Answer, 1 Opinion provide - Comment, 1 Assertion - Agreement, 1 Suggestion - Acceptance. 
This research offers some benefits for readers, the students of English Department and other researchers. After scrutinizing this study, the readers will gain understanding related to the phenomena of adjacency pairs. Not only the definition, but they will also be served with practical instances that are shown in the discussion. Moreover, they can see that adjacency pairs has types and patterns. Hopefully, the readers of this research can be more aware to the phenomena of adjacency pairs that they encounter frequently in their daily conversation; so that they have a new experience in language study, especially conversationaladjacency pairs.

The writer expected to give additional knowledge on conversation analysis especially on the study of adjacency pairs to the students of English Department especially. In addition, the research can be a reference for other researchers who are interested in the similar topic. Hopefully, they can invent new findings related to conversation adjacency pairs analysis.

\section{REFERENCES}

Coulthard, M. (1985). An Introduction to discourse analysis. New York: Longman group.

Cutting, J. 2002. Pragmatics and Discourse. London : Routledge.

Diningrum, A., \& Musyahda, L. (2016). Conversational implicature in 'Sarah Sechan' talk show of go green episodes. Retrieved June 27, 2018, from http://journal.unair.ac.id/download-fullpapers-anglicist1f34cb243cfull.pdf.

Eggins, S \& Slade, D. 1997. Analyzing Casual Conversation. London : Casel. Ellen

Degeneres' Interview with Malala Yousafzai. (2015). Retrieved June 25, 2018, from http://www.eamus.it/videos/malala-at-ellens.htm.

Fairclough, Norman. 2001. Language and Power. London: Longman.

Goddard, C. (2011). Semantic analysis: A practical introduction ( $2^{\text {nd }}$ edition). Oxford: Oxford University Press.

Ismaliyah, N. (2015). Conversation Analysis of Turn Taking Mechanism in Piers Morgan Tonight Talk Show. Retrieved June 25, 2018, from http://repository.uinjkt.ac.id/dspace/bitstream/123456789/27575/1/NURY ATUL\%20ISMALIYAH-FAH.pdf.

Levinson, S. C. (1983). Pragmatics. Cambridge : Cambridge University Press

Liddicoat, A. J. (2007). An Introduction to Conversation Analysis. London: Athenaeum Press Ltd.

Mazeland, H. (2006). Conversation Analysis in Keith B. (Ed). Encyclopedia of Language and Linguistics, Second Edition (153-162). Cambridge : Elsevier.

Mey, J.L. (1994). Pragmatics : an Introduction. Oxford : Blackwell. 
Moleong, L. Y. (2001). MetodePenelitianKualitatif. Bandung: PT RemajaRosdakarya.

Paltridge, B. (2000). Making Sense of Discourse Analysis. Queensland: antipodean Educational Enterprises.

Paltridge, B. (2006). Discourse Analysis: An Introduction. New ork: Continuum Pomerantz.

Pamungkas, P, G. (2012). Conversation Analysis of the Interview between Oprah Winfrey and the Founder of Facebook Mark Zuckerberg. Retrieved June 25, 2018, from http://eprints.dinus.ac.id/5974/1/THESIS_FULL.pdf.

Rheisa, N, S. (2014). A Conversation Analysis of Repair in the Oprah Winfrey Show: A Special Episode with Michael Jackson. Retrieved June 25, 2018 from

http:/eprints.uny.ac.id/19351/1/Nadya\%20Sivanya\%20Rheisa\%20102111 41038.pdf.

Richards, J.C. \& Schmidt, R. (1983). Conversation Analysis: Language and Communication. London: Longman.

Schegloff, E.A, (2006). Sequence Organization in Interaction: A Primer in Conversation Analysis I. New York: Cambridge University Press.

Schiffrin, Deborah. (1994). Approches to Discourse. Cambridge: Blackwell Publishers.

The adjacency pairs. (2018). Retrieved June 27, 2018, from, https://en.wikipedia.org/wiki/Adjacency_pairs.

Tracy, K. (2002). Everyday Talk: Building and Reflecting Identities. New York: Guilford Press.

Tylor, I. and Tylor, M. M. (1990). Psycholinguistics: Learning and Using Language. Englewood Cliffs, NJ: Prentice Hall.

Yule, G. 1996. Pragmatics. New York : Oxford University Press.

\section{APPENDIX}

Script: Conversation between Ellen Degeneres and Malala Yousafzai - Wednesday, September 9, 2015 
ELLEN : "You really are so impressive and so inspirational, and I am so happy to have you here. I watched the documentary, I have read your book, and if you haven't, you must read this. It's quite a story. So you were shot in the face at 15 years old and you have no anger toward the man who shot you. How is that possible?

MALALA : "I think they made a big mistake, because I was fighting for the right of education right from the beginning when the Taliban stopped girls from going to school. But I had this little bit of fear of that what would happen to me, how I would feel if someone attacks me, but after that incident when I was attacked, that fear just went away. And as I said in my speech at the United Nations, that my weakness, my fear, and my hopelessness died on that day. And I became stronger than before. And now I strongly believe that nothing can stop me in this mission and the campaign of education, to say that girls deserve the right to go to school and I-it's the love of people as well, that has encouraged me and helped me not to think about what I have been through in my life. When I see people praying for me, taking care of me, and sending cards and letters every day, it makes me stronger. It makes me stronger every day, and I feel that, whatever happened to me, I should now forget about it and continue my life with more courage and more work.

[cheers and applause]

ELLEN : "Well I am so glad that you came out of that experience as this person we are so lucky to have in the world, because you're making such a difference. You were in a coma for how long?"

MALALA : :At least a week.”

ELLEN : "And then it took you a long time how to speak and walk and everything again..."

MALALA : "Yes. Then my parents came, and the doctors, they would bring the cards that I had received, and I just could not believe it. It was astonishing that - I'm going through this difficult situation but there's so much love out there, and it's helping me to forget about all the pain that I'm going through." 
ELLEN : "Yeah, there was a lot of love, a lot of people, and it really did raise awareness in a way that never had happened before. Your parents are in the audience right now, and I know that your dad empowered you tremendously. How did he do that?"

MALALA : "Well, my father always says, 'Ask me not what I did, but ask me what I did not do,' and I did not clip her wings. So he has not clipped my wings, he has allowed me to fly as high as I can. This is how we want parents to be, to allow their children to fulfill their dreams, to achieve who they want to be. It's not that girls don't have the skill or don't have the talent to do something they want in their life, it's that they're stopped in society. So my father did not do that. He did not stop me; so I'm really thankful for him; also, to my mother for giving me the strength and the courage to move forward. A little bit to my brothers. A little bit."

ELLEN : "A little bit."

$<$ cheers and applause $>$

ELLEN : "That is so well put, in every one of those things. I love your brothers, by the way. It was good dancing with you. It was fun. So, you won the Nobel Peace Prize, and how did you find out you won?"

MALALA : "So, I was in my chemistry lesson in school, and -- just studying about atoms and those thing -- and suddenly my teacher came in, she surprised me and said, 'you have just won the Nobel Peace Prize." And I said, 'Okay.' And then I said, 'I want to finish my school, and-'cause I am standing up for education and I have been given this award because I am fighting for children's rights to go to school, so I deserve this right to study today in school, finish my school day, and then I'll go and have press interviews and stuff. So I finished that day."

ELLEN : "Right. Instead of talking to the press, you finished your school day. You just decided - well, and that's why you are who you are."

[laughter] 
ELLEN : "I think what's important here is that we take it for granted her, that girls go to school, and we are able to be educated, but I think that's really important for young girls here to understand that's not easy women and children are not treated the same way in other countries."

MALALA : "Well, I see children having this quality education, having all the facilities, classrooms, science labs, but unfortunately around this world, there are countries where children do not even have desks to sit, and they do not even have chairs. Some do not even have teachers in their school. Some do not even have schools at all. And I really think that education helps you to get an identity. It helps you to know about your basic human rights. It helps you to discover about yourself, about your talents, about your skills, and how you can help your community and your society. So, I did not want to be deprived of that, of that opportunity myself, and I want this for every child, that no child should be deprived of the basic human right of education."

$<$ cheers and applause $>$

ELLEN : "One thing I love about you, you're meeting all these world leaders, and you're not shy. You're meeting all these world leaders, and you're not shy. You're meeting all these world leaders, and you say exactly what you think they should be doing. You met with President Obama and you told him he should stop flying drones. You just said that to him..."

MALALA : “... and the Congress members I met in my last trip in June, and it's very important that you deliver your message to the right people. And if you say--"

[audience laughter]

ELLEN : "Remember that, so y'all go to him next time,ok?

[audience laughter] 
MALALA : "So if I like - if I feel shy, and if I think he would mind it, then these issues would never get highlighted. So it's telling the world, just reminding them of their duties. You're not asking to do something extra, but you're reminding them that these are their responsibility. They need to listen to their people's voices. We want them to take action. We want them to do something, and it's important that you highlight it to them."

ELLEN : "Yes, exactly. 18 years old, I was very similar to

this.” [cheers and applause, laughter]

ELLEN : “The problem that I see, because I've watched the documentary, and I've seen how many different places that you go to speak. Because you're 18 and you're shorter - you're not an adult-sized person yet."

[laughter]

ELLEN : "There's podiums that are too tall for you, so I got you something. So, it has a quote of mine, that says: 'Under every great woman is a tiny stepstool.'

MALALA : "Thank you. Thank you."

ELLEN : "Also, I know for your $18^{\text {th }}$ birthday, there was something more important for you than gifts and you wanted to give money to a school that you started, right? Well, I would like to - this is an amazing thing. This is an iPad Air 2 and it has over 100,000 educational apps and tens of thousands of textbooks at your fingertips in here, and I want to make sure all of your students in Lebanon have the best possible headstart, so they're going to get this as well. They're going to give you 200 of these."

MALALA : "Oh, thank you. Thank you so much."

ELLEN : "For more information on how you can donate to Malala Fund, you can go to malalafund.org. "He Named Me Malala" is in theaters October $2^{\text {nd }}$. We will be right back. Malala, everyone."

[cheers and applause, Malala stands on stepstool]. 